\title{
EFFECT OF TREE IDENTITY, TEMPORAL VARIATION AND EDAPHIC PARAMETERS ON THE STRUCTURE OF THE EDAPHIC COMMUNITY OF ORIBATID MITES IN AN EVERGREEN TROPICAL FOREST OF MEXICO
}

\author{
Villagomez, F..$^{1,2^{*}}$ - PAlacios-VARGas, J. G. ${ }^{1}$ - CAStaÑo-MenESES, G. $^{3}$ - CASTEllanos- \\ VARGAS, I. ${ }^{4}$ \\ ${ }^{1}$ Laboratorio de Ecología y Sistemática de Microartrópodos, Facultad de Ciencias, Universidad \\ Nacional Autónoma de México, 04510 Cd. Mx., México \\ ${ }^{2}$ Posgrado en Ciencias Biológicas, Unidad de Posgrado, Edificio D. Universidad Nacional \\ Autónoma de México, 04510 Cd. Mx., México \\ ${ }^{3}$ Unidad Multidisciplinaria de Docencia e Investigación, Facultad de Ciencias, Universidad \\ Nacional Autónoma de México, Campus UNAM 3001, Juriquilla, 76230 Querétaro, México \\ ${ }^{4}$ Grupo de Interacciones y Procesos Ecológicos, Departamento de Ecología y Recursos \\ Naturales, Facultad de Ciencias, Universidad Nacional Autónoma de México, 04510 Cd. Mx., \\ México \\ *Corresponding author \\ e-mail: lfvilagomez@gmail.com; phone: +52-55-5622-4902 \\ (Received $7^{\text {th }}$ Jun 2019; accepted $16^{\text {th }}$ Oct 2019)
}

\begin{abstract}
This paper analyzes the community structure of edaphic oribatid mites from the tropical forest at Los Tuxtlas, Veracruz, showing its monthly variation during only one year, considering two contrasting tree species and their relation with abiotic edaphic parameters. Randomly, five Astrocaryum mexicanum and Guarea glabra plants were chosen and near the stem of each one, a sample of soil was taken and processed in the same biological station with Berlese-Tullgren funnels. The most abundant families were Scheloribatidae, Oppiidae, Xylobatidae, Arceremaeidae, and Galumnidae. The KruskallWallis test showed that structure of oribatid mite community is not significative related to tree identity, which they are associated. Pearson's multiple correlation showed that the edaphic temperature is one of the most important abiotic factors in the structuring of oribatid mites communities. The abiotic variables explained $58 \%$ of oribatid community variance in its first two axes, with temporality and $\mathrm{CO}_{2}$ being the factors with most influence over the community. It is concluded that tree identity is not a factor that affects the structuring of oribatid mite communities in this tropical forest, while temporality, soil temperature and $\mathrm{CO}_{2}$ are the factors that most influence its establishment, this last factor as an indirect indicator of system productivity.
\end{abstract}

Keywords: arboreal identity, community diversity, temporality, Astrocaryum mexicanum, Guarea glabra

\section{Introduction}

From several decades edaphic communities have been observed to have a high value of biotic diversity, it is even estimated that our current knowledge covers less than $10 \%$ of the total number of species worldwide, due in part to the lack of studies, low efficiency in extraction methods and methodological issues (André et al., 2002). Together with the canopy, the need to study edaphic communities to understand the functioning of ecosystems has been evidenced, considering the soil as one of the last biotic frontiers (André et al., 1994). Anderson (1975) mentions that the mechanisms by which such diverse communities exist are poorly understood, and he named it as the 
"enigma of animal diversity in the soil". Since then, multiple factors associated with this phenomenon have been proposed, although most of them are focused on the litter diversity, reporting the environmental heterogeneity, content of organic matter, temperature, soil $\mathrm{pH}$, humidity and altitude as some of the determining factors of the communities (Perdue and Crossley, 1989; Urhan et al., 2006; Mumladze et al., 2015). Nielsen et al. (2010) hypothesized that small-scale environmental heterogeneity in respect to organic and mineral soil can be responsible of this high species richness, and recently Bernier (2018) emphasizes the importance of the type of humus for the establishment of the edaphic fauna, not only as a transition point between the soil and litter, but also as a kind of habitat with particular characteristics.

Forest soils are ecosystems characterized by being extremely fertile, in addition to having a great biodiversity in their first $20 \mathrm{~cm}$, which contributes in the cycle of nutrients and decompositions of organic matter (Gessner et al., 2010). In the edaphic communities of tropical forests, oribatid mites are numerically dominant organisms, and species richness of their biotic community is generally around 70 species (Kaneko et al., 2005; Mumladze et al., 2015). Wunderle (1992) reports 82 species of oribatids with an average density of 61,500 individuals per $\mathrm{m}^{2}$ for a low rain forest in Peru, while Ferreira et al. (2012) recorded 143 species of oribatids and up to 460 morphospecies for the Brazilian Amazon. In Mexico, there have been communities in tropical forests up to 120 species for the state of Quintana Roo (Vázquez, 2006).

It has been reported that abundance of oribatid mites show spatial and temporal (seasonal) variations, which reflects different dynamics of the microhabitat, although the taxonomic composition often does not reflect this pattern (Irmler, 2006; Wehner et al., 2018). Temporal variations in abundance are usually related to parameters such as temperature, humidity and even the availability of food, although sometimes these effects tend to influence particular species but frequently not all the community in general (Gergócs et al., 2011). Despite registering patterns of seasonal variation in his abundances, little is known about the role of the leaf litter and identity of the plants in relation to the stability of the community of mites that inhabit the soil near them.

Although the incorporation of leaf litter into the soil of ecosystems contribute with elements such as nitrogen, phosphorous and carbon differentially in relation to the plant species and senescent phase (Fonte and Schowalter, 2004), the diversity of oribatids on the litter is not much influenced by plant richness, nor by the accumulation of organic matter from different species (Kaneko et al., 2005), even with plants with allelochemical attributes that directly influence the chemical composition of the soil by the production of metabolites and other substances, are not capable of altering the structure of his communities (Osler and Beattie, 2001). However, in other papers this group has responded positively in relation to the increase in plant richness and diversity of litter (Kaneko and Salamanca, 1999; Hansen, 2000). Because most of the investigations are focused on analyzing the structure of the community in upper litter of the forest soils, it is not known if the community has this same behaviour belowground.

The tropical rain forest of Los Tuxtlas in the state of Veracruz is one of the last relicts of high tropical evergreen forest in Mexico. The Sierra of Los Tuxtlas is a mountain formation of volcanic origin, located in the coastal plain of the Gulf of Mexico, within this region is the Los Tuxtlas Tropical Field Station (hereafter referred to as LTS), this station was founded in 1968 and is operated by the Universidad Nacional Autonóma de México, actually has an area of 640 ha and its elevation range goes from 150 to $720 \mathrm{~m}$ asl (Dirzo et al., 1997). 
The palm Astrocaryum mexicanum Leibm. is the most abundant plant species of LTS, can register from 300 to 1,230 individuals per hectare and constitutes 20 to $61 \%$ of the total density of plants (Piñero et al., 1977), it has a longevity of 140 years and have heights of 1.5 to 6 meters (Piñero et al., 1984). This plant is favoured by disturbance, since its population grew from 1975 to 2013 with an average of $2.9 \%$ per year due to habitat alteration, edge effect and anthropogenic impact (Martínez-Ramos et al., 2016).

This palm is characterized by a monocaule stem of $10 \mathrm{~cm}$ thick and spiny leaves up to one and a half meters that have a development of 1.6 to 5 leaves per year in relation to the degree of light which they are exposed (Núñez-Castillo and Álvarez-Sánchez, 2003). Due to architecture, form of growth and the large number of thorns up to $6 \mathrm{~cm}$ that present in the stem, fruit and leaves, this plant has the ability to store a large amount of organic matter in its petioles, mainly of leaf litter from other trees, which gives an extra contribution of nitrogen and phosphorous by means of the decomposition on the plant that later reaches the soil by cauline flow (Raich, 1983; Álvarez-Sánchez et al., 2016).

Guarea glabra Vahl., also abounds in LTS (Álvarez-Sánchez and Guevara, 1999). It reaches heights of $25 \mathrm{~m}$ and has up to $30 \mathrm{~cm}$ in diameter (Coronado, 2006). It can persist for periods close to 100 years (Ibarra-Manríquez et al., 1997), has a strong trunk that begins to branch from near three meters and all the year constantly generates leaves, the fruits typically occur from May to July (Wenny, 1999) in reproductive season, its fruits cover small regions of soil, being a strong contribution of nutrients and organic matter to it.

Both plant species are part of different functional groups: A. mexicanum has a lower contribution of organic matter to the litter and soil and presents a slow decomposition rate (León, 2003) compared to G. glabra which is constantly generating and releasing leaves to the soil, also the genus Guarea present a quick green-leaf decomposition rate (Fonte and Schowalter, 2004). They have a different architecture and the first one enriches the soil by means of the continuous decomposition of organic matter that it captures in its leaves and petioles, incorporating nutrients into the soil by caulinar flow (Álvarez-Sánchez et al., 2016), while the contribution of nutrients and organic matter by G. glabra comes from the decomposition of leaves and temporarily from its fruits, incorporating magnesium, sodium and potassium mainly in the superior edaphic profiles (Barrantes and Ortiz, 2011).

The objective of this work is to analyze the effect of tree identity of two species of taxonomic and morphologically contrasting plants, monthly variation and soil abiotic parameters ( $\mathrm{pH}$, organic matter, organic carbon, $\mathrm{CO}_{2}$, porosity and soil moisture) on the diversity and structure of the belowground oribatid mite community in this Mexican tropical forest.

Our first hypothesis is that tree species will have a significant effect on the structure of the belowground oribatid community, we infer that in the soil associated with $G$. glabra the diversity, richness and abundance of oribatids will be greater due to the abundant and constant contribution of organic matter by this plant to the soil. $A$. mexicanum releases few leaves and most of the nutrients it contributes to the soil come from captured organic matter that decomposes on it, so that the amount of plant material and decomposition rate is lower, also we assume a different species composition in oribatid communities of both plants soils, with more species inhabiting soil related with G. glabra due to a bigger thickness of soil organic horizon in comparison of $A$. mexicanum. Our second hypothesis is that the community will show a significant variation in its richness, abundance, diversity and composition in relation to temporality 
(months), and soil abiotic parameters, being the families Galumnidae, Scheloribatidae, Haplozetidae, Oppidae, Phthiracaridae and Carabodidae more abundant as reported in literature for others tropical rainforest (Franklin et al., 2006; Caruso et al., 2019).

\section{Materials and methods}

\section{Study area and description}

LTS geographically is located in state of Veracruz, Mexico, between $18^{\circ} 34^{\prime}$ to $18^{\circ} 36^{\prime} \mathrm{N}$ and $95^{\circ} 04^{\prime}$ to $95^{\circ} 09^{\prime} \mathrm{W}$ (see Fig. 1). This station is mostly covered by evergreen tropical rain forest favoured by a warm climate with rainfall throughout the year, rainfall in the driest month is above $60 \mathrm{~mm}$ and are accentuated in the months of June to February marking a season of "rains" and one of "dry" in March to May, being September the month with greater precipitation. In addition, presents a scarce thermal variation, keeping mostly between 24 and $26^{\circ} \mathrm{C}$ (Soto and Gama, 1997).

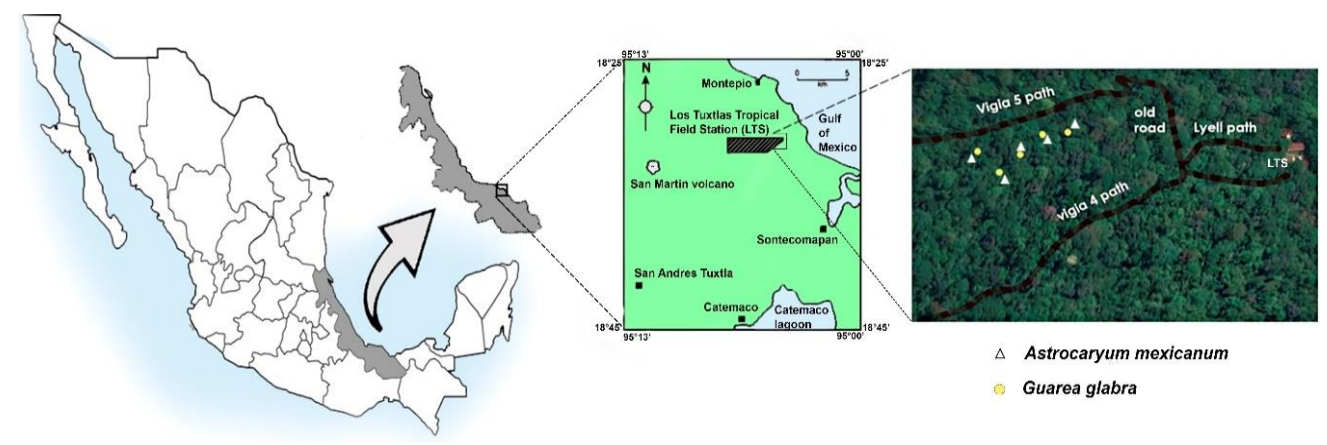

Figure 1. Location of Los Tuxtlas Tropical Field Station (LTS) in Veracruz, Mexico, and position of sampling sites within LTS (modified from Flores et al., 2014)

\section{Sampling method}

To analyze the effect of the leaf litter on the structure of belowground oribatid mite community, at random in a non-traveled area outside the walking paths Vigia 4 and 5 within the LTS (Fig. 1) five plants of G. glabra and another five of A. mexicanum were chosen in a paired design, the litter near the trunk was removed manually and immediately five samples of soil were taken associated with different arboreal individuals of $A$. mexicanum and five more with $G$. glabra with soil nucleators $(11 \mathrm{~cm}$ wide and $5 \mathrm{~cm}$ deep) (see Fig. 2). The material was collected monthly from March 2016 to February 2017 and processed in situ the same day of collection in Berlese-Tullgren funnels during six days (three days without light and three days with 25-watt bulbs).

The record of environmental parameters of temperature, relative humidity and $\mathrm{CO}_{2}$ was made by using a thermo-hygrometer IAQ-Calc ${ }^{\mathrm{TM}}$, model 8760 at ground level. Additionally, $100 \mathrm{~g}$ of soil were taken to determine the gravimetric humidity of the soil, porosity, $\mathrm{pH}$, percentage of carbon (\%C) and organic matter (\%O.M.).

\section{Laboratory techniques}

The soil $\mathrm{pH}$ was measured with $10 \mathrm{~g}$ of sifted soil diluted in distillate $\mathrm{H}_{2} \mathrm{O}$ with a $\mathrm{pH}$ meter. \%O.M. was obtained by Walkey-Black method (Walkey, 1947) with $0.2 \mathrm{~g}$ of sifted soil, percentage of carbon (\%C) was calculated as in Equation 1: 
For obtaining soil porosity (Jackson, 1976; Van Reeuwijk, 2002) we first measured apparent density $(A d)$ of soil by weighting a test tube of $10 \mathrm{ml}$, then added soil until 10 $\mathrm{ml}$, using a funnel and hit above-down from $20 \mathrm{~cm}$ ten times softly, posteriorly added again soil to refill $10 \mathrm{ml}$ and weight again the test tube, by resting the test tube weight and dividing it in test tube volume we obtain de apparent density $\left(\mathrm{g} / \mathrm{cm}^{3}\right)$, the density of solid particles of soil was obtained by pycnometer method (Blake and Hartge, 1986). First the dry pycnometer was weighted $(S)$, then $5 \mathrm{~g}$ of soil was added and the pycnometer is filled with water $(s+a)$, finally the soil is removed and the pycnometer is filled with water and weighted $(S+A)$. We calculate the of soil particles density $(S d)$ with Equation 2.

$$
S d=\frac{s}{S+A}-\mathrm{s}+\mathrm{a}
$$

The total porosity (Ptotal) was obtained using the apparent density and density of soil particles with Equation 3.

$$
\text { Ptotal }=\frac{(1-A d)(100)}{S d}
$$

The mites were separated and quantified manually under the stereoscopic microscope (Zeiss ${ }^{\mathrm{TM}}$, Stemi 2000), later they were mounted in semi-permanent preparations in Hoyer's solution. Identifications were made at the finest taxonomic level possible by dichotomous keys (Balogh and Balogh, 1992) and specialized literature for each family, those with identification problems were assigned to morphospecies, the specimens are deposited in the collection of Collembola and edaphic mites of the Laboratory of Ecology and Systematics of Microarthropods (LESM), Faculty of Sciences, UNAM, Mexico.

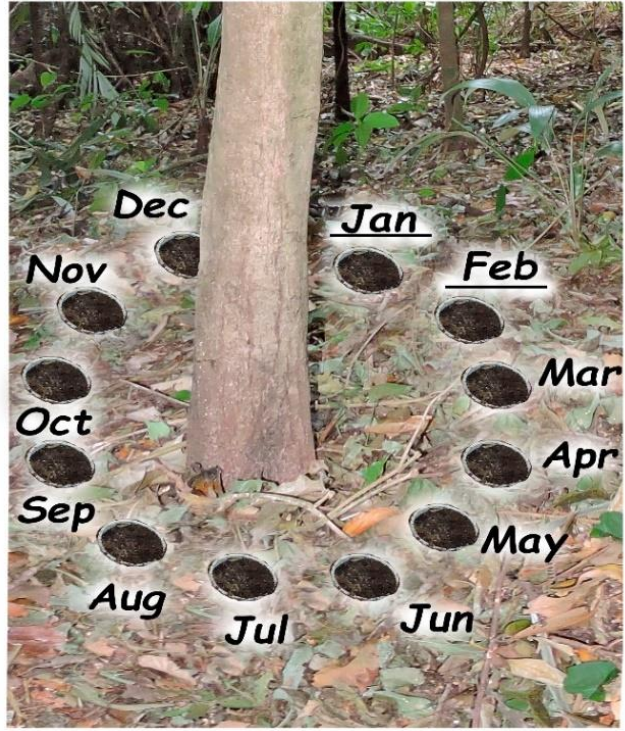

(a)

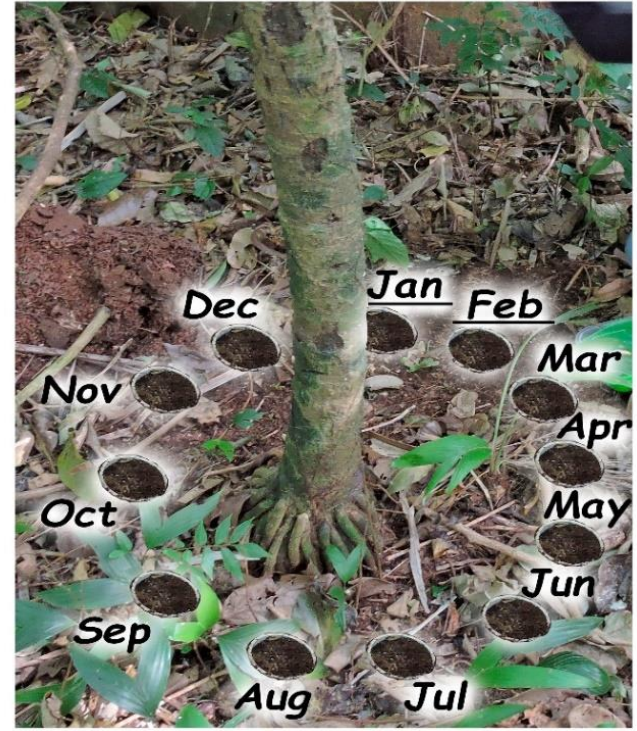

(b)

Figure 2. Schematic diagram of experimental setup. a Soil samples taken around Guarea glabra. $\boldsymbol{b}$ Soil samples taken around Astrocaryum mexicanum. Months underlined correspond to 2017 year, all others from 2016 


\section{Numerical and statistical analysis of the community}

To observe the fit of data and type of analysis to be performed, its normality was tested with Kolmogorov-Smirnov test in software R (R Core Team, 2016), and homoscedasticity with Statistica v.8.0. (Statsoft Inc, 2007). For each sample of tree species was obtained the abundance and oribatid species richness (S) by direct count, also, Pielou's equitativity $\left(J^{\prime}\right)$, Simpson's dominance $(D)$ and Shannon diversity index $\left(H^{\prime}\right)$ were calculated in PAST 3.22 software (Hammer et al., 2001) with Equations 4, 5 and 6 , respectively.

$$
\begin{gathered}
I^{\prime}=\frac{H}{\ln (s)} \\
D=\left(\frac{n_{i}}{n}\right)^{2} \\
H^{\prime}=-\sum \frac{n_{\tilde{i}}}{n} \ln \frac{n_{i}}{n}
\end{gathered}
$$

The effective species number $\left({ }^{1} D\right)$ was obtained through Shannon exponential with Equation 7 ( $\mathrm{e}^{\mathrm{H}}$; Jost, 2006).

$$
{ }^{1} D=\exp \left(H^{\prime}\right)
$$

To determine the effect of the identity of the plant species on the abundance, density, species richness, dominance and equity of the community of oribatid mites a nonparametric Kruskall-Wallis test was carried out between each plant community data in R software. Also, a t test with Shannon diversity index $\left(H^{\prime}\right)$ were performed in PAST 3.22 software for analyze possible variations in this community attribute between plants.

The relationship and significance between the community structure and soil abiotic factors was tested by a multiple correlation analysis of Pearson in software $\mathrm{R}$ with $\alpha=0.05$, including factors as abundance, density of individuals, richness $(S)$, diversity $\left(H^{\prime}\right)$, effective species number $\left({ }^{1} D\right)$, equity $\left(J^{\prime}\right)$, dominance $(D)$ and soil parameters like $\mathrm{CO}_{2}, \mathrm{pH}$, temperature, moisture, \%O.M., \% C and porosity. We performed a Canonical correspondence Analysis (CCA) using the CCorA function in vegan package (Oksanen et al., 2016) with Software R (R Core Team, 2016) to detect interactions between the community of oribatid mites and abiotic parameters, the envfit function ("Fits an Environmental Vector or Factor Onto An Ordination) was used with 999 permutations, to get the p-value or correlation of each variable with overall oribatid community, samples with total absence of specimens was removed from the analysis.

\section{Results}

A total of 2577 Oribatid mites with a mean monthly density of 289.49 ind $/ \mathrm{m}^{2}$, belonging to 41 families and 72 species (see Table 1 and Appendix 1). Most abundant families were Scheloribatidae (320 specimens), Oppiidae (288), Oripodidae (285), Protoribatidae (266), Arceremaeidae (222), Galumnidae (186) and Haplozetidae (148). Total abundance of oribatid present in soil of $G$. glabra $(1,321)$ was slightly higher than that recorded in A. mexicanum $(1,256)$. Most abundant species throughout the study 
were Scheloribates ca. grandiporosus, Tecteremaeus cornutus, Brasilobates sp. nov. and Benoibates sp. nov. with 9.5\%, 8.6\%, $8.4 \%$ and $8 \%$ respectively from the total of individuals.

Specific composition of oribatids between soils from trees was shared in $78 \%$, with 56 species in common between both communities, while seven were exclusively in $G$. glabra soils and nine in soils of A. mexicanum, although most of these records were made through the presence of a single specimen. Acrotritia ardua (March, April, May and August) and Rostrozetes cubanus (October, November and December) were the only species that present records in at least three months in soil of G. glabra and A. mexicanum respectively. Most abundant species related to G. glabra were Benoibates sp. nov. and Scheloribates ca. grandiporosus, while in A. mexicanum they were Tecteremaeus cornutus and Brasilobates sp. nov.

No homoscedasticity was found in the samples corresponding to both plant species, the Kolmogorov-Smirnof test showed that oribatids abundance was not a normal distribution $(\mathrm{D}=0.166, \mathrm{p}=0.0026)$, making it necessary to use nonparametric methods for its analysis.

No significant differences were found between the community of oribatids associated to G. glabra and A. mexicanum through the analysis of Kruskall-Wallis in relation to abundance $\left(\mathrm{X}^{2}=0.203 ; \mathrm{p}=0.651\right)$, density $\left(\mathrm{X}^{2}=0.204 ; \mathrm{p}=0.651\right)$, richness $(S)$ $\left(\mathrm{X}^{2}=0.117 ; \mathrm{p}=0.733\right)$, dominance $\left(D^{\prime}\right) \quad\left(\mathrm{X}^{2}=0.008 ; \mathrm{p}=0.927\right)$ and equity $\left(J^{\prime}\right)$ $\left(\mathrm{X}^{2}=1.8162 ; \mathrm{p}=0.178\right)$. The t-test for diversity between the community associated with these two plants using the Shannon entropy index $\left(H^{\prime}\right)$ showed no significant differences $\left(\mathrm{t}_{22}=1.7691, \mathrm{p}=0.077\right)$. Due to the lack of significant effects of tree species to the edaphic community of oribatids, their abundance from both plants was grouped for the analysis of temporal variation and its relationship with abiotic soil factors.

The highest abundance was recorded in March 2016 (Table 1), while the lowest was presented in February 2017; there is a second period of population increase in July and August 2016 with 372 and 305 specimens respectively. In March 2016, there were four species with the greatest abundance: Brasilobates sp. nov., Scheloribates ca. grandiporosus, Rostrozetes foveolatus and Galumnidae gen. nov. In July 2016 three species that showed high abundance in March again increase their population numbers; however, five different species increased their abundance in this season (Tecteremaeus cornutus, Benoibates sp. nov., Multioppia sp., Mesoplophora longisetosa, and Scheloribates praeincisus), which shows a temporal differentiation in relation to the specific composition of the oribatid community. The variation of the abundance of the oribatid species was very evident in some months (see Appendix 1), with families which live throughout the year (Arceremaeidae, Protoribatidae, Galumnidae, Epactozetidae, Neoliodidae, Oppiidae), others that are only temporary (Epilohmannidae, Mesoplophoridae, Malaconothridae) and some circumstantial like Cymbaeremaeidae, which normally can be found inhabiting in the trunk or canopy of trees.

The highest richness $(S)$ was presented in August (Table 1), followed by July and June, the lowest richness was recorded in February. The average diversity of all months according to the Shannon index was high $\left(H^{\prime}=2.96\right)$, the greatest true diversity $\left({ }^{1} D\right)$ was reported in November and July, while the lowest was in February and May, with an average of 20.24 effective species number per month. The highest dominance $(D)$ was registered in February due to the low number of specimens and the big abundance of a member of Truncozetes sturmi (Epactozetidae), and in May mainly due to the high abundance of three species of families Oppiidae (Multioppia sp.), Scheloribatidae (Scheloribates praeincisus) and Protoribatidae (Brasilobates sp. nov.). The values of the 
equity index $\left(J^{\prime}\right)$ showed quite homogeneous communities, because they were always above $J^{\prime}=0.75$, the month with the greatest equity were January and November, while the least equitable was May. Statistically significant differences between each collecting month and numerical attributes of oribatid mites community can be found in Appendix 2.

Table 1. Monthly numerical attributes of oribatid mites community in Los Tuxtlas, Veracruz

\begin{tabular}{c|c|c|c|c|c|c|c|c|c|c|c|c}
\hline Year & \multicolumn{10}{|c|}{$\mathbf{2 0 1 6}$} \\
\hline Month & Mar & Apr & May & Jun & Jul & Aug & Sep & Oct & Nov & Dec & Jan & Feb \\
\hline $\mathrm{N}$ & $\mathbf{4 9 5}$ & 297 & 185 & 243 & 372 & 305 & 197 & 116 & 166 & 113 & 49 & $\mathbf{3 9}$ \\
$\mathrm{Ind} / \mathrm{m}^{2}$ & $\mathbf{1 0 6 1}$ & 344.1 & 214.3 & 281.57 & 431 & 353.4 & 228.3 & 134.4 & 192.3 & 131 & 56.8 & $\mathbf{4 5 . 2}$ \\
$S$ & 35 & 36 & 32 & 41 & 46 & $\mathbf{5 0}$ & 39 & 36 & 39 & 28 & 24 & $\mathbf{1 3}$ \\
$H^{\prime}$ & 3.06 & 2.85 & 2.70 & 3.16 & 3.26 & 3.18 & 2.87 & 3.20 & $\mathbf{3 . 3 2}$ & 2.83 & 2.92 & $\mathbf{2 . 2 2}$ \\
${ }^{I} D$ & 21.52 & 17.34 & 14.99 & 23.66 & 26.23 & 24.07 & 17.63 & 24.68 & $\mathbf{2 7 . 9 1}$ & 17.03 & 18.54 & $\mathbf{9 . 2 9}$ \\
$D^{\prime}$ & 0.06 & 0.09 & 0.11 & 0.05 & 0.05 & 0.07 & 0.09 & 0.06 & $\mathbf{0 . 0 4}$ & 0.08 & 0.07 & $\mathbf{0 . 1 4}$ \\
$J^{\prime}$ & 0.86 & 0.79 & $\mathbf{0 . 7 8}$ & 0.85 & 0.85 & 0.81 & $\mathbf{0 . 7 8}$ & 0.89 & 0.90 & 0.85 & $\mathbf{0 . 9 2}$ & 0.86 \\
\hline
\end{tabular}

Maximum and minimum values of each parameter in bold

Abundance $(\mathrm{N})=$ total number of individuals; density $\left(\mathrm{Ind} / \mathrm{m}^{2}\right)=$ monthly mean of individuals $/ \mathrm{m}^{2}$; Species richness $(\mathrm{S})=$ Number of species; Shannon diversity index $\left(\mathrm{H}^{\prime}\right)=$ Shannon entropy index using $\ln$; true diversity $\left({ }^{1} \mathrm{D}\right)=$ Effective number of species with rank $1\left({ }^{\mathrm{q}}=1\right) ; \mathrm{D}^{\prime}=$ Dominance index; $\mathrm{J}^{\prime}=$ Pielou's equity (evenness)

Kruskall-Wallis analysis showed a significant relation between collecting month with abundance and density $\left(\mathrm{X}^{2}=56.53 ; \mathrm{p}<0.001\right)$, Richness $(S)\left(\mathrm{X}^{2}=51.99 ; \mathrm{p}<0.001\right)$, diversity $\left(H^{\prime}\right)$ and effective species number $\left({ }^{1} D\right)\left(\mathrm{X}^{2}=48 ; \mathrm{p}<0.001\right)$ and marginally significative with Dominance $\left(D^{\prime}\right)\left(\mathrm{X}^{2}=19.52 ; \mathrm{p}=0.052\right)$, only the relation with equity $\left(J^{\prime}\right)$ was not significative $\left(\mathrm{X}^{2}=14.653 ; \mathrm{p}=0.199\right)$. With which the monthly seasonality showed to be a key factor in the structuring of the community of oribatids in this jungle (Appendix 2).

For the Pearson's correlations between the edaphic parameters and the structural attributes of the community, only the relation between soil temperature with the density $(\mathrm{r}=0.641, \mathrm{p}=0.0009)$, richness $(\mathrm{r}=0.621, \mathrm{p}=0.0022)$, dominance $(\mathrm{r}=0.524$; $\mathrm{p}=0.0420)$ and true diversity $(\mathrm{r}=0.604, \mathrm{p}=0.004)$ were significative and positive, so the soil temperature is one of the factors that most influence the communities structure of these mites in the jungle; while porosity, percentage of organic matter, $\mathrm{pH}$, humidity and organic carbon did not have a significant interaction with the community of oribatids (Table 2).

The canonical correspondence analysis for the soil abiotic variables (Fig. 3) explains in its first two axes $58 \%$ of the variance in the community of oribatids (axis 1, 36\%, axis $2,22 \%)$. The monthly temporality shows a high negative correlation with axis $1(\mathrm{r}=-$ 0.9222 ); similarly, the percentage of soil $\mathrm{CO}_{2}$ shows a high negative correlation with axis $2(\mathrm{r}=-0.7211) ; \mathrm{CO}_{2}$ is indicative of the high primary productivity of the system and therefore of the high amount of food available for the oribatids (Herrera et al., 2001). The variables that correlate significantly with the ordination were temporality, soil temperature, $\mathrm{CO}_{2}$, soil relative humidity, percentage of organic matter and organic carbon (Table 3). The species most related to axis 1 are Licneremaeus discoidalis (Ld), 
Kaliptrazetes desaussurei $(\mathrm{Kd})$ and Berlesezetes peruensis $(\mathrm{Bp})$, these last two species are also related positively to axis 2, Klapperiches sp. nov., Protoribates capucinus and Epilohmannia pallida are the species more related negatively to this axis (Table 4).

Table 2. Pearson correlation coefficients and p-values of structural attribute of oribatid mites community and soil abiotic factors

\begin{tabular}{c|c|c|c|c|c|c|c|c|c|c|c|c|c}
\hline & $\mathbf{N}$ & ind/m2 & $\mathbf{S}$ & $\mathbf{H}^{\prime}$ & $\mathbf{1}_{\mathbf{D}}$ & $\mathbf{M o n t h}$ & $\mathbf{C O}_{\mathbf{2}}$ & $\mathbf{p H}$ & $\mathbf{P o r}$ & $\mathbf{s T}$ & $\mathbf{\%} \mathbf{C . O}$. & $\mathbf{\%} \mathbf{M} . \mathbf{O}$. & \% RH \\
\hline $\mathrm{N}$ & & $<.0001$ & $<.0001$ & $<.0001$ & $<.0001$ & $<.0001$ & $\mathrm{~ns}$ & $\mathrm{~ns}$ & $\mathrm{~ns}$ & $\mathrm{~ns}$ & $\mathrm{~ns}$ & $\mathrm{~ns}$ & $\mathrm{~ns}$ \\
ind/m2 & 0.836 & & $<.0001$ & $<.0001$ & $<.0001$ & $<.0001$ & $\mathrm{~ns}$ & $\mathrm{~ns}$ & $\mathrm{~ns}$ & 0.0009 & $\mathrm{~ns}$ & $\mathrm{~ns}$ & $\mathrm{~ns}$ \\
$\mathrm{~S}$ & 0.975 & 0.729 & & $<.0001$ & $<.0001$ & $<.0001$ & $\mathrm{~ns}$ & $\mathrm{~ns}$ & $\mathrm{~ns}$ & 0.002 & $\mathrm{~ns}$ & $\mathrm{~ns}$ & $\mathrm{~ns}$ \\
$\mathrm{H}^{\prime}$ & 0.935 & 0.735 & 0.97 & & $<.0001$ & 0.0003 & $\mathrm{~ns}$ & $\mathrm{~ns}$ & $\mathrm{~ns}$ & 0.0035 & $\mathrm{~ns}$ & $\mathrm{~ns}$ & $\mathrm{~ns}$ \\
${ }^{1} \mathrm{D}$ & 0.878 & 0.835 & 0.877 & 0.929 & & 0.0008 & $\mathrm{~ns}$ & $\mathrm{~ns}$ & $\mathrm{~ns}$ & 0.0004 & $\mathrm{~ns}$ & $\mathrm{~ns}$ & $\mathrm{~ns}$ \\
Month & -0.741 & -0.69 & -0.693 & -0.667 & -0.646 & & $\mathrm{~ns}$ & $\mathrm{~ns}$ & $\mathrm{~ns}$ & $<.0001$ & $\mathrm{~ns}$ & $\mathrm{~ns}$ & $\mathrm{~ns}$ \\
$\mathrm{CO}_{2}$ & -0.021 & -0.144 & 0.006 & 0.01 & -0.092 & -0.009 & & 0.042 & $\mathrm{~ns}$ & $\mathrm{~ns}$ & $\mathrm{~ns}$ & $\mathrm{~ns}$ & $\mathrm{~ns}$ \\
$\mathrm{pH}$ & -0.1 & 0.05 & -0.099 & -0.046 & 0.029 & 0.314 & -0.534 & & $\mathrm{~ns}$ & $\mathrm{~ns}$ & $\mathrm{~ns}$ & $\mathrm{~ns}$ & $\mathrm{~ns}$ \\
$\mathrm{Por}$ & -0.141 & -0.542 & -0.159 & -0.173 & -0.154 & -0.07 & -0.152 & -0.08 & & $\mathrm{~ns}$ & $\mathrm{~ns}$ & $\mathrm{~ns}$ & $\mathrm{~ns}$ \\
$\mathrm{sT}$ & 0.681 & 0.641 & 0.621 & 0.608 & 0.604 & -0.883 & 0.231 & -0.375 & -0.101 & & $\mathrm{~ns}$ & $\mathrm{~ns}$ & $\mathrm{~ns}$ \\
\%O.C. & -0.11 & -0.111 & -0.116 & -0.086 & -0.082 & 0.31 & 0.1 & 0.029 & -0.263 & -0.278 & & $\mathrm{~ns}$ & $\mathrm{~ns}$ \\
\%O.M. & -0.11 & -0.111 & -0.116 & -0.086 & -0.082 & 0.31 & 0.1 & 0.029 & -0.263 & -0.278 & 1 & & $<.0001$ \\
\%RH & -0.138 & -0.147 & -0.101 & -0.092 & -0.105 & 0.035 & 0.114 & -0.288 & 0.199 & -0.145 & -0.063 & $0.063 ;$ & \\
\hline
\end{tabular}

Scores below diagonal, $\mathrm{p}$-value above diagonal

Abundance $(\mathrm{N})=$ total number of individuals; density $\left(\mathrm{Ind} / \mathrm{m}^{2}\right)=$ monthly mean of individuals $/ \mathrm{m}^{2}$; Species richness $(\mathrm{S})=$ Number of species; Shannon diversity index $\left(\mathrm{H}^{\prime}\right)=$ Shannon entropy index using $\ln$; true diversity $\left({ }^{1} \mathrm{D}\right)=$ Effective number of species with rank $1\left({ }^{\mathrm{q}}=1\right)$; $\mathrm{D}^{\prime}=$ Dominance index; $\mathrm{J}^{\prime}=$ Pielou's equity index (evenness)

Por $=$ soil porosity; sT $=$ soil temperature; \%O.C. $=$ percentage of organic Carbon; \%O.M. = percentage of organic matter; $\% \mathrm{RH}=$ percentage of soil relative humidity; $\mathrm{ns}=$ non significant

Table 3. Envfit, CCA squared correlation coefficients $\left(r^{2}\right)$ and significance levels of the oribatid mites species abundance with respect to abiotic soil parameters

\begin{tabular}{c|c|c|c|c}
\hline & CCA1 & CCA2 & $\mathbf{r}^{\mathbf{2}}$ & p-value \\
\hline Month & -0.995 & -0.091 & 0.75 & $0.001^{* * *}$ \\
sT & -0.992 & -0.125 & 0.404 & $0.002^{* *}$ \\
$\mathrm{CO}_{2}$ & 0.473 & -0.880 & 0.516 & $0.001^{* * *}$ \\
\% RH & 0.719 & -0.694 & 0.353 & $0.006^{* *}$ \\
$\%$ O.M. & 0.687 & 0.726 & 0.249 & $0.050^{*}$ \\
$\%$ O.C. & 0.687 & 0.726 & 0.249 & $0.050^{*}$ \\
gH & -0.653 & -0.756 & 0.104 & 0.318 \\
pH & -0.876 & 0.482 & 0.160 & 0.137 \\
rD & -0.393 & -0.919 & 0.199 & 0.100 \\
aD & -0.368 & 0.929 & 0.060 & 0.493 \\
Por & -0.292 & -0.956 & 0.153 & 0.132 \\
Tree & 0.218 & 0.975 & 0.014 & 0.865 \\
\hline
\end{tabular}

*Significance level

$\%$ O.C.$=$ percentage of organic carbon; \%O.M. = percentage of organic matter; sT = soil temperature; $\mathrm{gH}=$ gravimetric humidity; $\mathrm{rD}=$ real density of soil; Por = soil porosity; $\mathrm{aD}=$ apparent density;

$\% \mathrm{RH}=$ relative humidity of soil 


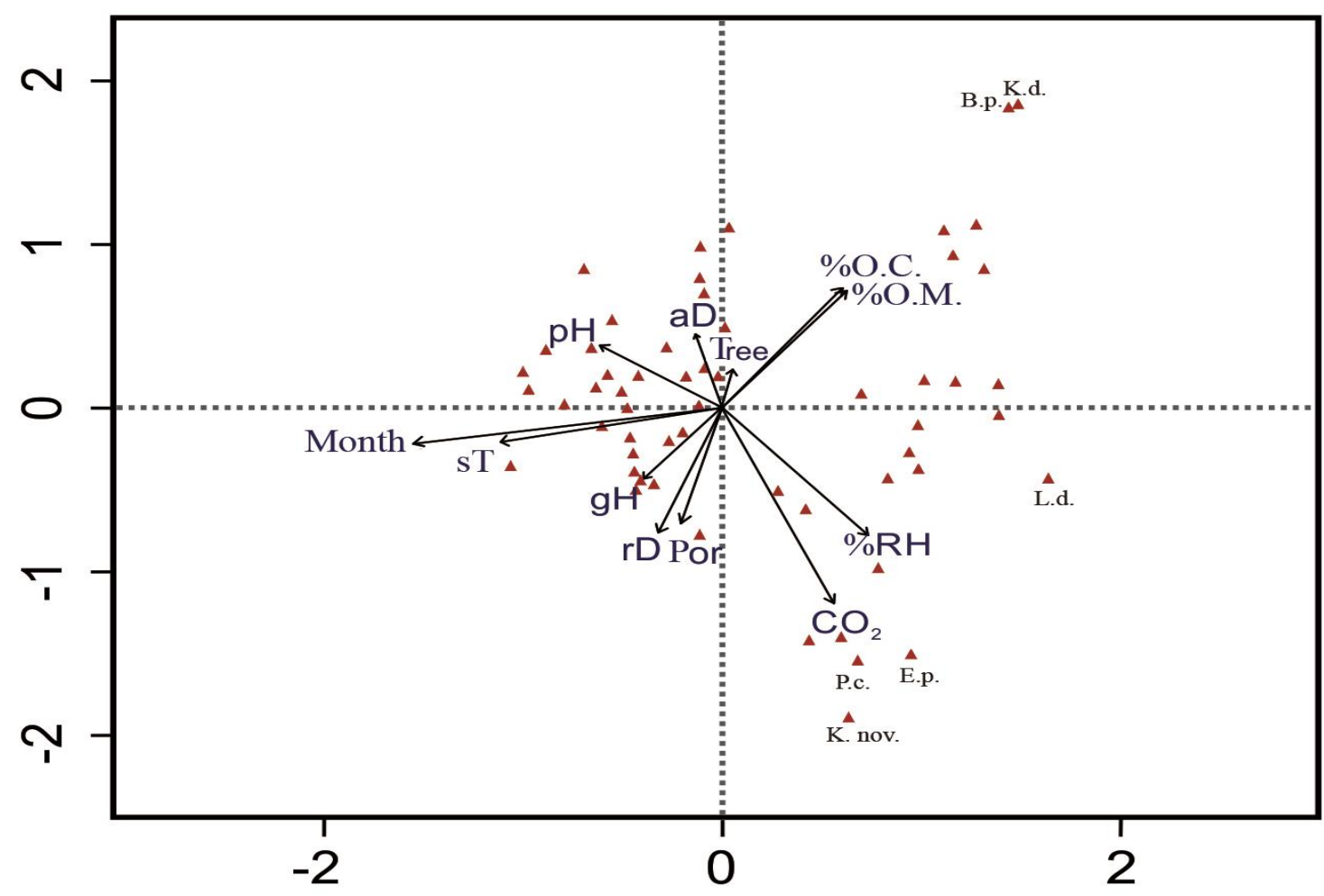

Figure 3. Canonical correspondence analysis between oribatid species abundance and edaphic abiotic parameters. Factors abbreviations: \%O.C. = percentage of organic carbon;

$\% O . M .=$ percentage of organic matter; $s T=$ soil temperature; $g H=$ gravimetric humidity; $r D=$ real density of soil; Por $=$ soil porosity; $a D=$ apparent density; $\% R H=$ relative humidity of soil. Species abbreviations: L.d. = Licneremaeus discoidalis; K.nov. = Klapperiches $\mathrm{sp}$. nov.; K.d. $=$ Kalyptrazetes desaussurei; B.p. $=$ Berlesezetes peruensis; P.c. $=$ Protoribates capucinus; E.p. = Epilohmannia pallida

Table 4. CCA species scores of the species more related with Axis 1 and 2

\begin{tabular}{c|c|c|c}
\hline Family & Genus and species & CCA axis 1 & CCA axis 2 \\
\hline Licneremaeidae & Licneremaeus discoidalis & $\mathbf{1 . 6 4 0 0 6 2}$ & -0.420947 \\
Microzetidae & Kalyptrazetes desaussurei & $\mathbf{1 . 4 7 4 6 9 8}$ & 1.849525 \\
Microzetidae & Berlezesetes peruensis & $\mathbf{1 . 4 6 8 6 5 8}$ & 1.846099 \\
Carabodidae & Klapericches sp. nov. & 0.639038 & $\mathbf{- 1 . 9 0 2 6 7 2}$ \\
Protoribatidae & Protoribates capucinus & 0.684869 & $\mathbf{- 1 . 5 5 1 1 4 4}$ \\
Epilohmannidae & Epilohmannia pallida & 0.9484 & $\mathbf{- 1 . 5 1 3 9 7 7}$ \\
\hline
\end{tabular}

Bold number denotes to which axis are more related

\section{Discussion}

There is a large amount of information about the close interaction between the community of edaphic fauna and plant species, especially because they provide a large amount of organic matter and their roots exudates to the soil, which are captured by litter and reintegrated into the soil with the help of degrading organisms (Bardgett and Wardle, 2010). This litter has mainly a structural function for oribatids, maintaining habitat heterogeneity necessary to sustain their complex communities, without significant influence 
of the identity of the litter (even with more than 25 species of leaves) on the community of these mites (Kaneko et al., 2005), this is due to the decrease of leaf litter quality as the decomposition process progresses, and also to the high range of food resources that can be consumed by the oribatids (Scheu, 2005; Kaneko et al., 2005).

Contrary to our first hypothesis, specific identity of the trees studied (A. mexicanum and G. glabra) is not a determinant factor on the communities structure of soil oribatids in this tropical forest, so there are no significant differences in abundance, richness, dominance, equity and diversity; also, a similarity of $72 \%$ was observed among their species, and many of them were represented by a single specimen (Appendix 1). This can be because the litter under these plants in natural conditions is still heterogeneous and the decomposition process and abundant rains unmasks the possible differences between types of litter and generates a redistribution of organic matter and nutrients (Donoso et al., 2013). Finally, because the low evolutionary relationship between these mites and the plant resources they ingest, is common to find oribatids with general food habits (Wardle, 2006; Donoso et al., 2010, 2013) feeding indistinctly of any type of organic matter.

It is known that the abundance of mites depends on the seasonality of the ecosystems, since the quantity and quality of the organic matter in litter varies with the season and climate. In a tropical forest in Panama, a decrease in the abundance and richness of oribatids was observed in the last months of the year (November) since litter tended to be shallower (Donoso et al., 2013).

In this study, the total abundance (2,577 specimens) and richness (72 spp.) was lower than that reported by Minor et al. (2017a), who registered 10,585 specimens and 139 spp. in a tropical forest of Vietnam. Also the density of oribatids per sample in this forest goes from 12 to $984 \mathrm{ind} / \mathrm{m}^{2}$, with a monthly mean of $289.5 \mathrm{ind} / \mathrm{m}^{2}$ (see Table 1) which was low compared to the records (between 4,000 and 40,000 ind $/ \mathrm{m}^{2}$ ) for other tropical forests (Bluhm et al., 2016; Minor et al., 2017a); although there are records at the soil of rainforest Vietnam, with densities lower than $180 \mathrm{ind} / \mathrm{m}^{2}$ (Minor et al., 2017b). The densities found in LTS are still below even compared with a dry forest in western Mexico, where densities greater than $8,000 \mathrm{ind} / \mathrm{m}^{2}$ have been recorded (Palacios-Vargas et al., 2007).

In respect to our second hypothesis, our results show a similar tendency in the decrease of oribatids abundance at winter season, which is generally related to a reduction in the specific richness and diversity in the community, registering the three lowest abundances in December, January and February, and the highest in March, which is explained by the presence of a large number of tropical and northern cyclones that naturally occur in the region in the winter season from November to January (Soto and Gama, 1997), and that during our sampling, they were present very intensively from October to February, flooding large areas of the jungle and part of our collection points (University Network of Atmospheric Observatories, RUOA, http://www.ruoa.unam.mx), which generates a large number of soils oribatids perish, migrate vertically, or they resort to some morphophysiological strategy to survive, however the success and survival time to the floods is dependent on each species (Bardel and Pfingstl, 2018; Smrẑ, 1996; Pequeno et al., 2017), also only the families Scheloribatidae, Oppidae, Oripodidae, Protoribatidae and Arceremaeidae were abundant in this forest which possess generalist feeding habits, contrary to our expectations Phthiracaridae and Carabodidae was low abundant families.

The edaphic temperature result one of the main determinants of community structure of oribatids, since there is a great dependence of poikilothermic animals with this 


$$
-14632 \text { - }
$$

parameter for physiology (mainly metabolic and respiratory) throughout their life cycle (Stamou et al., 1995); this relationship is generally reported as negative, so that as the temperature increases, the abundance of many groups of the mesofauna decreases, among them the oribatid mites. Maximum lethal temperatures for them are close to $40{ }^{\circ} \mathrm{C}$ (Wehner et al., 2018; Ermilov and Lochynska, 2008; Bezci et al., 2017), other factors that significantly influence these communities are content of organic matter, soil $\mathrm{pH}$, porosity and humidity (Urhan et al., 2006; Wissuwa et al., 2013); however, in our study none of these parameters were significant, suggesting that among the factors analyzed, only the soil temperature plays a key role in structuring oribatids in this rainforest.

The analysis of canonical correspondence explains about $60 \%$ of the variance of the community of oribatids in relation to temporality and the percentage of $\mathrm{CO}_{2}$, the temporality has been previously addressed as a structuring character of the communities of these mites; however the $\mathrm{CO}_{2}$ has been used as a measure of the productivity of the system, observing that the greater amount of this compound, tropical plant species increase their photosynthetic rate, increasing their productivity and possibly their hydric status (Herrera et al., 2001). However, high levels of $\mathrm{CO}_{2}$ generate changes in the edaphic flora and microbiota, which in short-term studies do not show enough interaction to modify the structure of the oribatid mites (Haimi et al., 2005), although in studies of modification of the amount of $\mathrm{CO}_{2}$ in soil in the long term, after 18 months in plots with increase of this compound with $200 \mathrm{ppm}$ above the environmental values, there are significant differences in the decrease of the populations of these mites in up to $61 \%$, due to the variation in the microbiota and litter quality (Hansen et al., 2001).

\section{Conclusions}

No significant effect of tree identity was found on the structure of the oribatid mite community in Los Tuxtlas rainforest. Soil constitutes a continuum in conditions and resources as proposed by Wehner et al. (2016) in its hypothesis about litter, being considered as a connecting bridge between the organisms; besides that litter quality decreases as the decomposition process advances and therefore they end up masking the differential properties of leaves (Scheu, 2005; Kaneko et al., 2005); however, it is relevant to mention that contrary cases have been reported for temperate forests (Eissfeller et al., 2013).

The community structure of oribatids mites showed significant differences in relation to collecting months, finding in general terms two large demographic increases in March 2016 and July 2016, which show a differentiation in the specific composition and allow a greater richness in the community.

Within the soil abiotic factors only soil temperature had a significant relationship with soil community according to Pearson correlation analysis; however, in the CCA ordination with envfit, additionally to temporality and edaphic temperature, the $\%$ of $\mathrm{CO}_{2}$, the edaphic relative humidity, percentage of O.M. and O.C. was also significant and have an effect on the structuration. Even so, analyzed factors are insufficient to explain the whole variation in the community structure of the Oribatid mites.

Subsequent analyzes are necessary to know if the plant identity does not affect the communities of oribatid mites inhabiting the litter or even the trunks or canopy of morphological and functionally contrasting trees in this tropical ever-green forest, and also compare these results with others tropical forest for the world. 


$$
-14633-
$$

Acknowledgments. We thank to the Postgraduate doctoral program in Biological Sciences of the UNAM for all the support given during the realization of this work. CONACyT gave a scholarship to the senior author for this doctoral study. This project was supported by the project PAPIIT (DGAPA, UNAM) IN214816: "Microarthropod ecology of Los Tuxtlas forest, Veracruz" in charge of José G. Palacios Vargas. We had logistic help from the personal of Tropical Biology Station of Los Tuxtlas, Veracruz, mainly from Rosamond Coates and Martha Madora, Maira Montejo gave assistance in the ecological analyzes, Ricardo Iglesias supported the taxonomic determination of oribatid mites, Tila Pérez support with valuable suggestion for the improvement of this paper.

\section{REFERENCES}

[1] Anderson, J. M. (1975): The Enigma of Soil Animal Species Diversity. - In: Vanek, J. (ed.) Progress in Soil Ecology. Academia, Prague.

[2] André, H. M., Noti, M.-I., Lebrun, P. (1994): The soil fauna: the other last biotic frontier. Biodiversity and Conservation 3: 45-46.

[3] André, H. M., Ducarme, X., Lebrun, P. (2002): Soil biodiversity: myth, reality or conning? - Oikos 96: 3-24.

[4] Álvarez-Sánchez, J., Guevara, S. (1999): Litter interception on Astrocaryum mexicanum Liebm. (Palmae) in a Tropical Rain Forest. - Biotropica 31(1): 89-92.

[5] Álvarez-Sánchez, J., Barajas-Guzmán, G., Campo, J., León, R. (2016): Inorganic nitrogen and phosphorous in stemflow of the palm Astrocaryum mexicanum Liebm. located in Los Tuxtlas, Mexico - Tropical Ecology 57(1): 45-55.

[6] Balogh, J., Balogh, P. (1992): The Oribatid Mites Genera of the World. - Hungarian Natural History Museum, Budapest.

[7] Bardel, L., Pfingstl, T. (2018): Resistance to flooding of different species of terrestrial oribatid mites (Acari, Oribatida) - Soil Organisms 90(2): 71-77.

[8] Bardgett, R. D., Wardle, D. A. (2010): Aboveground-Belowground Linkages: Biotic Interactions, Ecosystem Processes, and Global Change. - Oxford University Press, Oxford, UK.

[9] Barrantes, T., Ortiz, R. (2011): Nutrient distribution in Guarea glabra Vahl. in San Lorencito river basin at Alberto ML Brenes Biological Reserve of San Ramón, Alajuela, Costa Rica. - Biocenosis 25(1-2): 68-78.

[10] Bernier, N. (2018): Hotspots of biodiversity in the underground: a matter of humus form? Applied Soil Ecology 123: 305-312.

[11] Bezci, T., Altun, A., Barán, Ş. (2017): Monthly variation of oribatid subspecies Eremaeus hepaticus cordiformis Grandjean, 1934 (Acari). - Sakarya Üniversitesi Fen Bilimleri Enstitüsü Dergisi 21(6): 1331-1335.

[12] Blake, G. R., Hartge, K. H. (1986): Particle Density. - In: Kutle, A. (ed.) Methods of Soil Analysis. Part I. Physical and Mineralogical Methods. ASA, Madison, WI.

[13] Bluhm, C., Scheu, S., Maraun, M. (2016): Temporal fluctuations in oribatid mites indicate that density-independent factors favour parthenogenetic reproduction. - Experimental and Applied Acarology 68: 387-407.

[14] Caruso, T., Schaefer, I., Monson, F., Keith, A. M. (2019): Oribatid mites show how climate and latitudinal gradients in organic matter can drive large-scale biodiversity patterns of soil communities. - Journal of Biogeography 46: 611-620.

[15] Coronado, I. M. (2006): Five new species of Guarea (Meliaceae), two from the Guarea glabra Vahl complex, in Central America. - Novon 16(4): 462-467.

[16] Dirzo, R., Gónzalez-Soriano, E., Vogt, R. C. (1997): General Introduction. - In: GónzalezSoriano, E., Dirzo, R., Vogt, R. C. (eds.) Natural History of Los Tuxtlas. National Autonomous University of Mexico, México D. F. (in Spanish).

[17] Donoso, D. A., Johnston, M. K., Kaspari, M. (2010): Trees as templates for tropical litter arthropod diversity. - Oecologia 164: 201-211. 
[18] Donoso, D. A., Johnston, M. K., Clay, N. A., Kaspari, M. E. (2013): Trees as templates for trophic structure of tropical litter arthropod fauna. - Soil Biology and Biochemistry 61: 4551.

[19] Eissfeller, V., Langenbruch, C., Jacob, A., Maraun, M., Scheu, S. (2013): Tree identity surpasses tree diversity in affecting the community structure of oribatid mites (Oribatida) of deciduous temperate forests. - Soil Biology and Biochemistry 63: 154-162.

[20] Ermilov, S., Łochyńska, M. (2008): The influence of temperature on the development time of three oribatid mites species (Acari, Oribatida). - North-Western Journal of Zoology 4(2): 274-281.

[21] Ferreira, R. N. C., Franklin, E., Pereira de Souza, J. L., de Moraes, J. (2012): Soil oribatid mite (Acari: Oribatida) diversity and composition in semi-deciduous forest in eastern Amazonia and comparison with the surrounding savanna matrix. - Journal of Natural History 46(33-34): 2131-2144.

[22] Flores, J. J., Coates, R. I., Sánchez-Cordero, V., Mendieta, V. J. (2014): Terrestrial mammals of the Tropical Biology Station of Los Tuxtlas. - University Digital Magazine 15(4): 1-10 (in Spanish).

[23] Fonte, S. J., Schowalter, T. D. (2004): Decomposition of greenfall vs. senescent foliage in a tropical forest ecosystem in Puerto Rico. - Biotropica 36(4): 474-482.

[24] Franklin, E., Santos, E. M. R., Albuquerque, M. I. C. (2006): Diversity and distribution of oribatid mites (Acari:Oribatida) in a lowland rain forest in Peru and in several environments of the Brazilians states of Amazonas, Rondônia, Roraima and Pará. - Brazilian Journal of Biology 66(4): 999-1020.

[25] Gergócs, V., Garamvölgyi, A., Homoródi, R., Hufnagel, L. (2011): Seasonal change of oribatid mite communities (Acari, Oribatida) in three different types of microhabitats in an oak forest. - Applied Ecology and Environmental Research 9(2): 181-195.

[26] Gessner, M. O., Swan, M. S., Dang, C. K., McKie, B. G., Bardgett, R. D., Wall, D. H., Hättenschwiler, S., Gasser, P. (2010): Soil animals alter plant litter diversity effects on decomposition. - Proceedings of the National Academy of Sciences of the United States of America 102: 1519-1524.

[27] Haimi, J., Laamanen, J., Penttinen, R., Räty, M., Koponen, S., Kellomäki, S., Niemelä, P. (2005): Impacts of elevated $\mathrm{CO} 2$ and temperature on the soil fauna of boreal forests. Applied Soil Ecology 30(2): 104-112.

[28] Hammer, Ø., Harper, D. A. T., Ryan, P. D. (2001): PAST: Paleontological Statistics software package for education and data analysis. - Paleontologia Electronica 4(1): 1-9.

[29] Hansen, R. A. (2000): Effects of habitat complexity and composition on a diverse litter microarthropod assemblage. - Ecology 81(4): 1120-1132.

[30] Hansen, R. A., Williams, R. S., Degenhardt, D. C., Lincoln, D. E. (2001): Non-litter effects of elevated $\mathrm{CO} 2$ on forest floor microarthropod abundances. - Plant and soil 236: 139-144.

[31] Herrera, A., Fernández, M. D., Rengifo, E., Tezara, W. (2001): Effect of high concentration of $\mathrm{CO} 2$ on photosynthesis in tropical species. - Interciencia 26(10): 469-471 (in Spanish).

[32] Ibarra-Manríquez, G., Martínez-Ramos, M., Dirzo, R., Núñez-Farfán, J. (1997): The Vegetation. - In: Gónzalez-Soriano, E., Dirzo, R., Vogt, R. C. (eds.) Natural History of Los Tuxtlas. National Autonomous University of Mexico, Mexico, D. F.

[33] Irmler, U. (2006): Climatic and litter fall effects on collembolan and oribatid mite species and communities in a beech wood based on a 7 years investigation. - European Journal of Soil Biology 42(1): 51-62.

[34] Jackson, M. L. (1976): Chemical Analysis of Soils. - Omega, Barcelona (in Spanish).

[35] Jost, L. (2006): Entropy and diversity. - Oikos 113: 363-374.

[36] Kaneko, N., Salamanca, E. F. (1999): Mixed leaf litter effects on decomposition rates and soil microarthropod communities in an oak-pine stand in Japan. - Ecological Research 14: 131-138.

[37] Kaneko, N., Sugawara, Y., Miyamoto, T., Hasegawa, M., Hiura, T. (2005): Oribatid mite structure and tree species diversity: a link? - Pedobiologia 49: 521-529. 
[38] León, R. (2003): Effects of Decomposition, Frugivorous and Removal of Fruits and Seeds of Tree Species on Patterns of Decomposition in Situ in Rainforest Soil. - In: ÁlvarezSánchez, J., Naranjo-García, E. (eds.) Soil Ecology in the Tropical Humid Forest of Mexico. National Autonomous University of Mexico, Mexico, D. F.

[39] Martínez-Ramos, M., Ortiz-Rodríguez, I. A., Piñero, D., Dirzo, R., Sarukhán, J. (2016): Anthropogenic disturbances jeopardize biodiversity conservation within tropical rainforest reserves. - Proceedings of the National Academy of Sciences 113(19): 5323-5328.

[40] Minor, M. A., Babenko, A. B., Ermilov, S. G. (2017a): Oribatid mites (Acari: Oribatida) and springtails (Collembola) in alpine habitats of southern New Zealand. - New Zealand Journal of Zoology 44(1): 65-85.

[41] Minor, M. A., Ermilov, S. G., Anichkin, A. E. (2017b): Biodiversity of soil oribatid mites (Acari: Oribatida) in a tropical highland plateaux, Bi Doup-Nui Ba National Park, Southern Vietnam. - Tropical Ecology 58(1): 45-55.

[42] Mumladze, L., Murvanidze, M., Maraun, M., Salakaia, M. (2015): Oribatid mite communities along an elevational gradient in Sairme Georgia (Caucasus). - Experimental and Applied Acarology 66(1): 41-51.

[43] Nielsen, U. N., Osler, G. H. R., Campbell, C. D., Neilson, R., Burslem, D. F. R. P., van der Wal, R. (2010): The enigma of soil animal species diversity revisited: the role of smallscale heterogeneity. - PLoS One 5(7): e11567.

[44] Núñez-Castillo, O., Álvarez-Sánchez, F. J. (2003): Arbuscular mycorrhizae of the palm Astrocaryum mexicanum in disturbed and undisturbed stands of a Mexican tropical forest. Mycorrhiza 13: 271-276.

[45] Oksanen, J., Blanchet, F. G., Friendly, M., Kindt, R., Legendre, P., McGlinn, D., Minchin, R., O’Hara, R. B., Simpson, L., Solymos, P., Stevens, M. H. H., Szoecs, E., Wagner, H. (2016): Vegan: Community Ecology Package. R package. Version 2.4-1. https://CRAN.R-project.org/package=vegan.

[46] Osler, G. H. R., Beattie, A. J. (2001): Contribution of oribatid and mesostigmatid soil mites in ecologically based estimates of global species richness. - Austral Ecology 26: 70-79.

[47] Palacios-Vargas, J. G., Castaño-Meneses, G., Gómez-Anaya, J. A., Martínez-Yrizar, A., Mejía-Recamier, B. E., Martínez-Sánchez, J. (2007): Litter and soil arthropods diversity and density in a tropical dry forest ecosystem in western Mexico. - Biodiversity and Conservation 16: 3703-3717.

[48] Pequeno, P. A. C. L., Franklin, E., Norton, R. A., Wellington de Morais, J., Guilherme, D. R. (2017): Spatial abundance pattern of a common soil arthropod changes suddenly with season in a tropical rainforest. - Pedobiologia 63: 46-51.

[49] Perdue, J. C., Crossley, D. A. (1989): Vertical distribution of soil mites (Acari) in conventional and no-tillage agricultural systems. - Biology and Fertility of Soils 9(2): 135138.

[50] Piñero, D., Sarukhán, J., González. E. (1977): Demographic studies in plants. Astrocaryum mexicanum Liebm. I. Populations structure. - Bulletin of the Botanical Society of Mexico 37: 69-118 (in Spanish).

[51] Piñero, D., Martínez-Ramos, M., Sarukhán, J. (1984): A population model of Astrocaryum mexicanum and a sensitive analysis of its finity rate of increase. - The Journal of Ecology 72: 977-991.

[52] Raich, J. W. (1983): Understory palms as nutrient traps: a hypothesis. - Brenesia 21: 119129.

[53] R Core Team (2016): R: A Language and Environment for Statistical Computing. - R Foundation for Statistical Computing, Vienna, Austria. http://www.R-project.org/.

[54] Scheu, S. (2005): Linkages between Tree Diversity, Soil Fauna and Ecosystem Processes. In: Scherer-Lorenzen, M., Korner, C., Schulze, E. (eds.) Forest Diversity and Function Temperate and Boreal Systems. Springer, Berlin. 
[55] Soto, M., Gama, L. (1997): Climes. - In: Gónzalez-Soriano, E., Dirzo, R., Vogt, R. C. (eds.) Natural History of Los Tuxtlas. National Autonomous University of Mexico, México D. F. (in Spanish).

[56] Smrẑ, J. (1996): Some Aspects of the Life Strategy of Oribatid Mites (Oribatida). - In: Mitchell, R., Horn, D. J., Needham, G. R., Welbourn, W. C. (eds.) Acarology IX: Vol. 1, Proceedings. Ohio Biological Survey, Columbus, USA.

[57] Stamou, G. P., Asikidis, M. D., Argyropoulou, M. D., Iatrou, G. D. (1995): Respiratory responses of oribatid mites to temperature changes. - Journal of Insect Physiology 41(3): 229-233.

[58] Statsoft, Inc. (2007): STATISTICA Data Analysis Software System, Versión 8.0. Statsoft, Inc., Tulsa, OK.

[59] Urhan, R., Katilmis, Y., Kahveci, A. Ö. (2006): Vertical distribution of oribatid mites (Acari: Oribatida) and some ecological parameters affecting the distribution pattern in south-west Turkey. - Zoology in the Middle East 37: 99-105.

[60] Van Reeuwijk, L. P. (1998): Procedures for soil analysis. - International Soil Reference and Information Center (ISRIC), Wageningen, Netherlands.

[61] Vázquez G., M. M. (2006): Oribatid mites from tropical jungles of Mexico and Belice. Caos Conciencia 1: 19-23 (in Spanish).

[62] Walkey, A. (1947): A critical examination of a repid method for determining organic carbon in soils: effect of variations in digestion conditions and of inorganic soil costituents. - Soil Science 63: 251-264.

[63] Wardle, D. A. (2006): The influence of biotic interactions on soil biodiversity. - Ecology Letters 9: 870-886.

[64] Wehner, K., Heethoff, M., Bruckner, A. (2018): Seasonal fluctuation of oribatid mite communities in forest microhabitats. - PeerJ 6: e4863.

[65] Wehner, K., Norton, R. A., Blüthgen, N., Heethoff, M. (2016): Specialization of oribatid mites to forest microhabitats - the enigmatic role of litter. - Ecosphere 7(3): e01336

[66] Wenny, D. G. (1999): Two-stage dispersal of Guarea glabra and G. kunthiana (Meliaceae) in Monteverde, Costa Rica. - Journal of Tropical Ecology 15: 481-496.

[67] Wissuwa, J., Salamon, J. A., Frank, T. (2013): Oribatida (Acari) in grassy arable fallows are more affected by soil properties than habitat age and plant species. - European Journal of Soil Biology 59: 8-14.

[68] Wunderle, I. (1992): Arboricolous and edaphic oribatids (Acari) in the lowland rainforest of Panguana, Peru. - Amazoniana 12: 119-142.

\section{APPENDIX}

Appendix 1. Taxonomic list, occurrence and abundance of oribatid mites from the Los Tuxtlas Tropical Field Station related to A. mexicanum (A) and G. glabra $(G)$

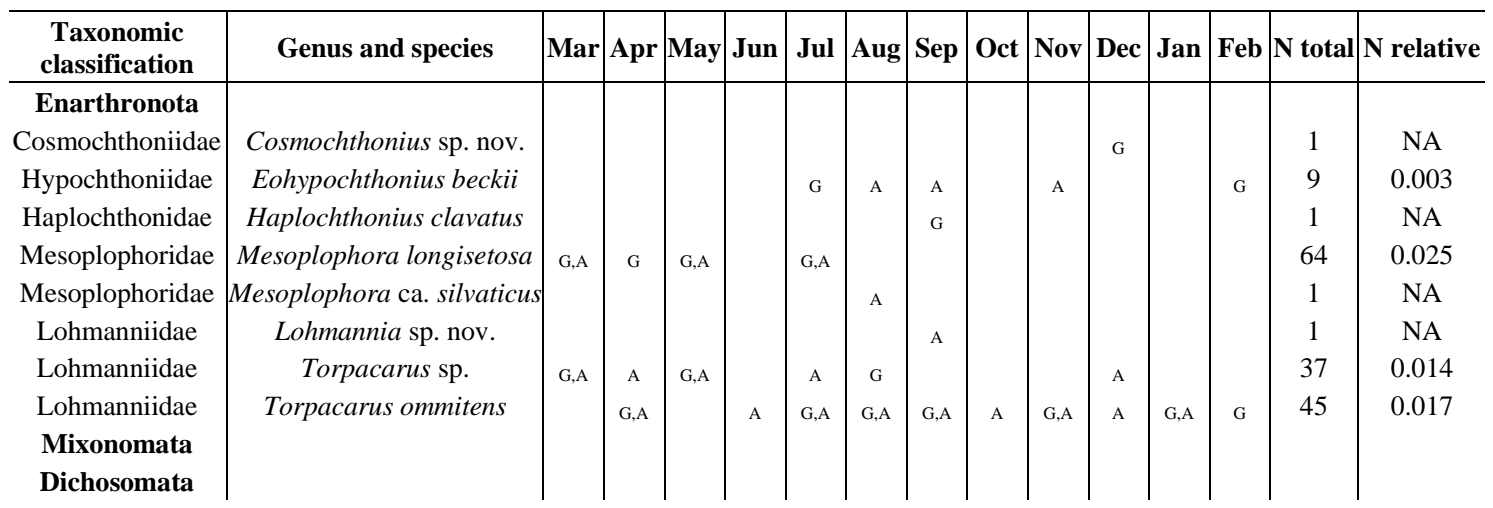




\begin{tabular}{|c|c|c|c|c|c|c|c|c|c|c|c|c|c|c|c|}
\hline Epilohmannidae & Epilohmannia minuta & & & & & $\mathrm{G}, \mathrm{A}$ & A & G & & & & & & 4 & 0.002 \\
\hline Epilohmannidae & Epilohmannia pallida & & & $\mathrm{G}, \mathrm{A}$ & & G,A & & G & & $\mathrm{G}, \mathrm{A}$ & & & & 9 & 0.003 \\
\hline Euphthiraridae & Acrotritia ardua & A & $\mathrm{G}, \mathrm{A}$ & A & G & & G & & & & & & & 8 & 0.003 \\
\hline Euphthiraridae & $\begin{array}{c}\text { Euphthiracarus ca. } \\
\text { breviculus }\end{array}$ & & & & & & & G & G & & G & & & 5 & 0.002 \\
\hline Phthiracaridae & Hoplophorella sp.1 & & $\mathrm{G}, \mathrm{A}$ & $\mathrm{G}, \mathrm{A}$ & G & $\mathrm{G}, \mathrm{A}$ & G & & & & A & $\mathrm{G}, \mathrm{A}$ & & 25 & 0.010 \\
\hline Phthiracaridae & Hoplophorella scapellata & $\mathrm{G}, \mathrm{A}$ & $\mathrm{G}, \mathrm{A}$ & $\mathrm{G}, \mathrm{A}$ & A & A & A & & A & G & & & & 24 & 0.009 \\
\hline Phthiracaridae & Hoplophorella ca. eximia & & G & A & $\mathrm{G}, \mathrm{A}$ & G & G,A & & & & & G & & 8 & 0.003 \\
\hline Holosomata & & & & & & & & & & & & & & & \\
\hline Trhypochthoniidae & Archegozetes magnus & & G & A & & & & $\mathrm{G}, \mathrm{A}$ & G & & & & & 31 & 0.012 \\
\hline Crotoniidae & Camisia ca. horrida & & $\mathrm{G}, \mathrm{A}$ & & & & & & & & & & & 6 & 0.002 \\
\hline Malaconothridae & $\begin{array}{l}\text { Malaconothrus ca. } \\
\text { silvaticus }\end{array}$ & G & & & G & & & & & & & & & 2 & 0.001 \\
\hline Brachypylina & & & & & & & & & & & & & & & \\
\hline Pycno & & & & & & & & & & & & & & & \\
\hline Arceremaeidae & Tecteremaeus cornutus & $\mathrm{G}, \mathrm{A}$ & $\mathrm{G}, \mathrm{A}$ & $\mathrm{G}, \mathrm{A}$ & $\mathrm{G}, \mathrm{A}$ & $\mathrm{G}, \mathrm{A}$ & G,A & $\mathrm{G}, \mathrm{A}$ & $\mathrm{G}, \mathrm{A}$ & $\mathrm{G}, \mathrm{A}$ & A & A & G & 222 & 0.086 \\
\hline Basilobelbidae & Basilobelba sp. & $\mathrm{G}, \mathrm{A}$ & A & G & A & $\mathrm{G}$ & & & & & A & & & 10 & 0.004 \\
\hline Compactozetidae & Reticulocepheus ca. grandis & $\mathrm{G}, \mathrm{A}$ & $\mathrm{G}, \mathrm{A}$ & G & G & G,A & $\mathrm{G}$ & $\mathrm{G}, \mathrm{A}$ & A & & & & & 38 & 0.015 \\
\hline Charassobatidae & Charassobates tuberosus & $\mathrm{G}, \mathrm{A}$ & $\mathrm{G}, \mathrm{A}$ & & G & $\mathrm{G}, \mathrm{A}$ & G & & & G & A & G & & 17 & 0.007 \\
\hline Carabodidae & Cubabodes verrucatus & $\mathrm{G}, \mathrm{A}$ & $\mathrm{G}, \mathrm{A}$ & $\mathrm{G}, \mathrm{A}$ & $\mathrm{G}, \mathrm{A}$ & $\mathrm{G}, \mathrm{A}$ & G,A & G & G & $\mathrm{G}, \mathrm{A}$ & G,A & G & & 65 & 0.025 \\
\hline Carabodidae & $\begin{array}{c}\text { Carabodes (Klapericches) } \\
\text { sp. nov. }\end{array}$ & & & & G & & G & & & & & & & 2 & 0.001 \\
\hline Carabodidae & $\begin{array}{c}\text { Carabodes } \\
\text { (Phyllocarabodes) sp. }\end{array}$ & & & G & & A & & & & & & & & 4 & 0.002 \\
\hline Ceratoppiidae & Ceratorchestes baloghi & A & A & A & G & G & G & & $\mathrm{A}$ & G & A & & & 17 & 0.007 \\
\hline Cymbaeremaeidae & Scapheremaeus tonathiu & & & G & & & & & & & & & & 1 & NA \\
\hline Damaeidae & Epidamaeus sp. nov. & $\mathrm{G}, \mathrm{A}$ & & & G & G & G & G & & & & & & 10 & 0.004 \\
\hline Dampfiellidae & Dampfiella procera & A & & & G & A & $\mathrm{G}$ & A & $\mathrm{G}, \mathrm{A}$ & & & & & 8 & 0.003 \\
\hline Eremulidae & Eremulus rigidisetosus & $\mathrm{G}, \mathrm{A}$ & & & $\mathrm{G}, \mathrm{A}$ & G,A & G & G & G,A & $\mathrm{G}, \mathrm{A}$ & & & & 25 & 0.010 \\
\hline Tetracondylidae & Flagellocepheus sagittatus & & A & & & & & & A & & & & & 3 & 0.001 \\
\hline Damaeoliodidae & Fosseremus ca. laciniatus & & & & & & & G & & & & & & 1 & 0.001 \\
\hline Hermanniellidae & Hermaniella sp. nov. & & & & G & A & A & & & & & & & 6 & 0.002 \\
\hline Hermanniellidae & $\begin{array}{l}\text { Sacculobates ca. } \\
\text { heterotrichus }\end{array}$ & & & & & & G & & & G & & & & 3 & 0.001 \\
\hline Hermanniellidae & Sacculobates horologiorum & $\mathrm{G}, \mathrm{A}$ & $\mathrm{G}, \mathrm{A}$ & A & $\mathrm{G}, \mathrm{A}$ & $\mathrm{G}, \mathrm{A}$ & G,A & G & G & G & & G & & 39 & 0.015 \\
\hline Heterobelbidae & Heterobelba oxapampensis & A & & & & & & & & & & & & 1 & NA \\
\hline Xenillidae & Xenillus ca. fazendae & $\mathrm{G}, \mathrm{A}$ & A & & & G,A & A & A & & & & & & 8 & 0.003 \\
\hline Microtegeidae & Microtegeus similis & & & & & A & & & & & & & & 2 & 0.001 \\
\hline Microtegeidae & Microtegeus borhidii & $\mathrm{G}, \mathrm{A}$ & A & & & G & G,A & G & A & $\mathrm{G}, \mathrm{A}$ & A & A & & 56 & 0.022 \\
\hline Nanhermannidae & Cyrthermannia simplex & $\mathrm{G}, \mathrm{A}$ & $\mathrm{G}, \mathrm{A}$ & A & $\mathrm{G}, \mathrm{A}$ & $\mathrm{G}, \mathrm{A}$ & A & G & & G & & A & G & 30 & 0.012 \\
\hline Nanhermannidae & Cyrthermannia ca. florens & & & & & & & & A & & & & & 1 & NA \\
\hline Neoliodidae & Teleioliodes madininensis & $\mathrm{G}, \mathrm{A}$ & $\mathrm{G}, \mathrm{A}$ & G & G & $\mathrm{G}, \mathrm{A}$ & $\mathrm{G}, \mathrm{A}$ & A & $\mathrm{G}, \mathrm{A}$ & A & G & $\mathrm{A}$ & G & 44 & 0.017 \\
\hline Oppiidae & Multioppia sp. & $\mathrm{G}, \mathrm{A}$ & $\mathrm{G}, \mathrm{A}$ & $\mathrm{G}, \mathrm{A}$ & $\mathrm{G}, \mathrm{A}$ & $\mathrm{G}, \mathrm{A}$ & G & G & $\mathrm{A}$ & $\mathrm{G}, \mathrm{A}$ & $\mathrm{G}, \mathrm{A}$ & A & G & 129 & 0.050 \\
\hline Oppiidae & Stachyoppia curvispina & & A & A & $\mathrm{G}, \mathrm{A}$ & $\mathrm{G}, \mathrm{A}$ & G,A & $\mathrm{G}, \mathrm{A}$ & G,A & $\mathrm{G}, \mathrm{A}$ & G,A & G & & 112 & 0.043 \\
\hline Oppiidae & Arcoppia sp. & & & & $\mathrm{G}, \mathrm{A}$ & & G & $\mathrm{G}, \mathrm{A}$ & $\mathrm{A}$ & $\mathrm{G}, \mathrm{A}$ & A & & & 47 & 0.018 \\
\hline Poronoticae & & & & & & & & & & & & & & & \\
\hline Ceratozetidae & Fuscozetes sp. nov. & $\mathrm{G}, \mathrm{A}$ & A & A & A & & G & & & A & $\mathrm{A}$ & & & 26 & 0.010 \\
\hline Epactozetidae & Truncozetes sturmi & G,A & A & G,A & G & $\mathrm{G}, \mathrm{A}$ & $\mathrm{G}, \mathrm{A}$ & $\mathrm{G}, \mathrm{A}$ & $\mathrm{G}, \mathrm{A}$ & $\mathrm{G}, \mathrm{A}$ & $\mathrm{G}, \mathrm{A}$ & $\mathrm{A}$ & G & 94 & 0.036 \\
\hline Galumnellidae & Galumnopsis sp. nov. & $\mathrm{G}, \mathrm{A}$ & A & & & A & $\mathrm{G}$ & A & & A & & & & 26 & 0.010 \\
\hline Galumnidae & $\begin{array}{c}\text { Galumna (Orthogalumna) } \\
\text { sp. nov. }\end{array}$ & & & & & & G & G & G,A & & & & & 4 & 0.002 \\
\hline Galumnidae & Notogalumna sp. nov. & & & & A & & & & & & & & & 1 & NA \\
\hline Galumnidae & Pergalumna dactylaris & G & A & G,A & $\mathrm{G}, \mathrm{A}$ & A & $\mathrm{G}, \mathrm{A}$ & $\mathrm{G}, \mathrm{A}$ & & $\mathrm{G}, \mathrm{A}$ & & A & & 27 & 0.010 \\
\hline Galumnidae & $\begin{array}{c}\text { Pergalumna } \\
\text { hypergranulosa }\end{array}$ & $\mathrm{G}, \mathrm{A}$ & & A & A & $\mathrm{G}, \mathrm{A}$ & G & A & & G & & & & 21 & 0.008 \\
\hline Galumnidae & Pergalumna obsidiana & G & G & & & G & & A & $\mathrm{G}, \mathrm{A}$ & $\mathrm{G}, \mathrm{A}$ & & & & 14 & 0.005 \\
\hline Galumnidae & Pergalumna ekaterinae & $\mathrm{G}, \mathrm{A}$ & $\mathrm{G}, \mathrm{A}$ & $\mathrm{G}, \mathrm{A}$ & $\mathrm{G}, \mathrm{A}$ & $\mathrm{G}, \mathrm{A}$ & $\mathrm{G}, \mathrm{A}$ & G & G,A & A & A & $\mathrm{A}$ & A & 59 & 0.023 \\
\hline Galumnidae & Galumnidae gen. nov. & $\mathrm{G}, \mathrm{A}$ & $\mathrm{G}, \mathrm{A}$ & G,A & $\mathrm{G}, \mathrm{A}$ & G,A & A & A & G,A & $\mathrm{G}, \mathrm{A}$ & A & A & G & 60 & 0.023 \\
\hline Haplozetidae & $\begin{array}{l}\text { Rostrozetes. ca. } \\
\text { dimorphochartes }\end{array}$ & & & & G & & A & & G & $\mathrm{G}, \mathrm{A}$ & & & & 7 & 0.003 \\
\hline Haplozetidae & Rostrozetes cubanus & & & & & & & & A & A & A & & & 3 & 0.001 \\
\hline Haplozetidae & Rostrozetes foveolatus & G,A & $\mathrm{G}, \mathrm{A}$ & $\mathrm{G}, \mathrm{A}$ & $\mathrm{G}, \mathrm{A}$ & $\mathrm{G}, \mathrm{A}$ & G.A & $\mathrm{G}, \mathrm{A}$ & A & $\mathrm{G}, \mathrm{A}$ & $\mathrm{G}, \mathrm{A}$ & $\mathrm{G}, \mathrm{A}$ & & 138 & 0.05 \\
\hline
\end{tabular}




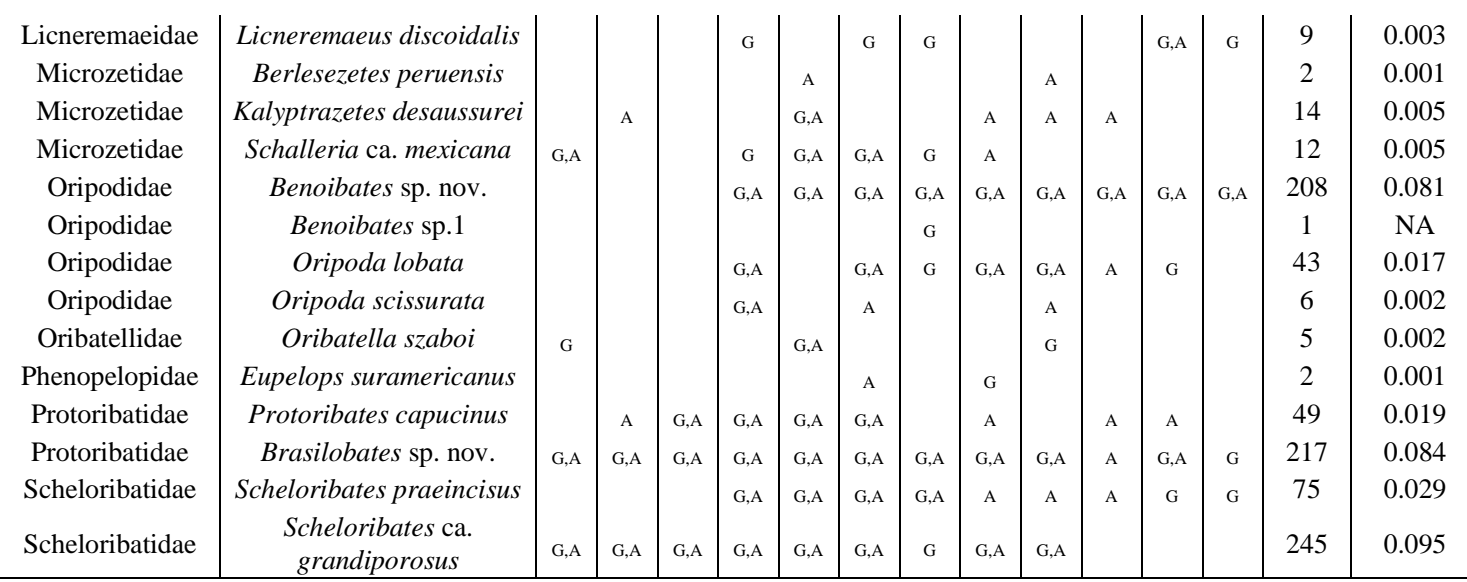

$\mathrm{N}$ total $=$ total abundance $\mathrm{N}$ relative $=$ relative abundance

Appendix 2. Kruskall-Wallis Post-hoc comparisons of collecting month with structural parameters of oribatid mites community from Los Tuxtlas, Veracruz. Dunn's test with Bonferroni adjustment. Scores below diagonal, p-value above diagonal. In bold in each side the significant values with $\alpha=0.05$. Abundance $(N)$ and density $\left(\mathrm{ind} / \mathrm{m}^{2}\right)$ registered the same tendency, for which only one is reported; Species richness (S); Dominance (D'); Shannon diversity (entropy) index $\left(H^{\prime}\right)$ and true diversity $\left({ }^{1} D\right)$ registered the same tendency, for which only one is reported; $J^{\prime}=$ Pielou's equity (evenness)

\begin{tabular}{c|c|c|c|c|c|c|c|c|c|c|c|c}
\hline $\boldsymbol{I n d}^{\prime} \boldsymbol{m}^{2}$ & Mar & Apr & May & Jun & Jul & Aug & Sep & Oct & Nov & Dec & Jan & Feb \\
\hline Mar & & 1 & 1 & 1 & 1 & 1 & $\mathbf{0 . 0 2 1 5} *$ & $\mathbf{0 . 0 1 5 4} *$ & 0.071 & $\mathbf{0 . 0 0 2 4} *$ & $\mathbf{0 . 0 0 0 1} *$ & $\mathbf{0 . 0 0 0 0}$ \\
Apr & 1.483 & & 1 & 1 & 1 & 1 & 1 & 1 & 1 & 0.427 & 0.035 & $\mathbf{0 . 0 1 0 7 *}$ \\
May & 2.148 & 0.666 & & 1 & 1 & 1 & 1 & 1 & 1 & 1 & 0.301 & 0.112 \\
Jun & 1.830 & 0.347 & -0.318 & & 1 & 1 & 1 & 1 & 1 & 1 & 0.113 & 0.038 \\
Jul & 0.839 & -0.643 & -1.309 & -0.990 & & 1 & 0.336 & 0.258 & 0.853 & 0.058 & $\mathbf{0 . 0 0 3 0 *}$ & $\mathbf{0 . 0 0 0 7 *}$ \\
Aug & 1.180 & -0.302 & -0.968 & -0.650 & 0.341 & & 0.853 & 0.674 & 1 & 0.175 & $\mathbf{0 . 0 1 1 5 *}$ & $\mathbf{0 . 0 0 3 2} *$ \\
Sep & $\mathbf{3 . 4 0 9}$ & 1.926 & 1.261 & 1.579 & 2.569 & 2.229 & & 1 & 1 & 1 & 1 & 1 \\
Oct & $\mathbf{3 . 4 9 9}$ & 2.016 & 1.351 & 1.669 & 2.660 & 2.319 & 0.090 & & 1 & 1 & 1 & 1 \\
Nov & 3.068 & 1.585 & 0.920 & 1.238 & 2.229 & 1.888 & -0.341 & -0.431 & & 1 & 1 & 1 \\
Dec & $\mathbf{3 . 9 6 8}$ & 2.486 & 1.820 & 2.139 & 3.129 & 2.788 & 0.560 & 0.470 & 0.900 & & 1 & 1 \\
Jan & $\mathbf{4 . 7 5 6}$ & 3.274 & 2.608 & 2.926 & $\mathbf{3 . 9 1 7}$ & $\mathbf{3 . 5 7 6}$ & 1.347 & 1.257 & 1.688 & 0.788 & & 1 \\
Feb & $\mathbf{5 . 0 7 8}$ & $\mathbf{3 . 5 9 5}$ & 2.930 & 3.248 & $\mathbf{4 . 2 3 9}$ & $\mathbf{3 . 8 9 8}$ & 1.669 & 1.579 & 2.010 & 1.109 & 0.322 & \\
\hline
\end{tabular}

\begin{tabular}{c|c|c|c|c|c|c|c|c|c|c|c|c}
\hline S & Mar & Apr & May & Jun & Jul & Aug & Sep & Oct & Nov & Dec & Jan & Feb \\
\hline Mar & & 1 & 0.5017 & 1 & 1 & 1 & 0.0401 & 0.1228 & 0.4348 & $\mathbf{0 . 0 0 6 1} *$ & $\mathbf{0 . 0 0 0 6} *$ & $\mathbf{0 . 0 0 0 0} *$ \\
Apr & 1.526 & & 1 & 1 & 1 & 1 & 1 & 1 & 1 & 0.8904 & 0.1894 & 0.0288 \\
May & 2.428 & 0.901 & & 1 & 1 & 1 & 1 & 1 & 1 & 1 & 1 & 0.5017 \\
Jun & 1.668 & 0.142 & -0.760 & & 1 & 1 & 1 & 1 & 1 & 1 & 0.2896 & 0.0474 \\
Jul & 0.338 & -1.188 & -2.089 & -1.330 & & 1 & 0.1241 & 0.3427 & 1 & $\mathbf{0 . 0 2 2 3} *$ & $\mathbf{0 . 0 0 2 6} *$ & $\mathbf{0 . 0 0 0 2}^{*}$ \\
Aug & 0.863 & -0.663 & -1.565 & -0.805 & 0.525 & & 0.5826 & 1 & 1 & 0.1333 & $\mathbf{0 . 0 2 0 2 *}$ & $\mathbf{0 . 0 0 2 2} *$ \\
Sep & 3.236 & 1.710 & 0.808 & 1.568 & 2.898 & 2.373 & & 1 & 1 & 1 & 1 & 1 \\
Oct & 2.901 & 1.375 & 0.473 & 1.233 & 2.563 & 2.038 & -0.335 & & 1.0000 & 1.0000 & 1.0000 & 1 \\
Nov & 2.479 & 0.953 & 0.052 & 0.811 & 2.141 & 1.616 & -0.757 & -0.422 & & 1.0000 & 1.0000 & 0.5776 \\
Dec & $\mathbf{3 . 7 3 8}$ & 2.212 & 1.310 & 2.070 & $\mathbf{3 . 4 0 0}$ & 2.875 & 0.502 & 0.837 & 1.259 & & 1.0000 & 1 \\
Jan & $\mathbf{4 . 2 8 8}$ & 2.762 & 1.861 & 2.621 & $\mathbf{3 . 9 5 0}$ & $\mathbf{3 . 4 2 6}$ & 1.053 & 1.388 & 1.809 & 0.551 & & 1 \\
Feb & $\mathbf{4 . 8 5 5}$ & 3.329 & 2.428 & 3.187 & $\mathbf{4 . 5 1 7}$ & $\mathbf{3 . 9 9 2}$ & 1.619 & 1.954 & 2.376 & 1.117 & 0.567 & \\
\hline $\boldsymbol{D}^{\prime}$ & Mar & Apr & May & Jun & Jul & Aug & Sep & Oct & Nov & Dec & Jan & Feb \\
\hline Mar & & 1 & 0.6354 & 1 & 1 & 1 & 1 & 0.6922 & 1 & 0.1044 & 0.1619 & 0.9349 \\
Apr & -1.489 & & 1 & 1 & 1 & 1 & 1 & 1 & 1 & 1 & 1 & 1
\end{tabular}




\begin{tabular}{c|c|c|c|c|c|c|c|c|c|c|c|c} 
May & -2.341 & -0.852 & & 1 & 1 & 1 & 1 & 1 & 1 & 1 & 1 & 1 \\
Jun & -1.858 & -0.370 & 0.482 & & 1 & 1 & 1 & 1 & 1 & 1 & 1 & 1 \\
Jul & -0.511 & 0.977 & 1.829 & 1.347 & & 1 & 1 & 1 & 1 & 0.4844 & 0.7041 & 1 \\
Aug & -0.752 & 0.736 & 1.588 & 1.106 & -0.241 & & 1 & 1 & 1 & 0.9197 & 1 & 1 \\
Sep & -0.871 & 0.617 & 1.469 & 0.987 & -0.360 & -0.119 & & 1 & 1 & 1 & 1 & 1 \\
Oct & -2.308 & -0.820 & 0.032 & -0.450 & -1.797 & -1.556 & -1.437 & & 1 & 1 & 1 & 1 \\
Nov & -1.743 & -0.254 & 0.598 & 0.116 & -1.231 & -0.990 & -0.871 & 0.566 & & 1 & 1 & 1 \\
Dec & -2.951 & -1.463 & -0.611 & -1.093 & -2.440 & -2.199 & -2.080 & -0.643 & -1.209 & & 1 & 1 \\
Jan & -2.813 & -1.325 & -0.473 & -0.955 & -2.302 & -2.061 & -1.942 & -0.505 & -1.071 & 0.138 & & 1 \\
Feb & -2.193 & -0.704 & 0.148 & -0.334 & -1.681 & -1.440 & -1.321 & 0.116 & -0.450 & 0.759 & 0.621 &
\end{tabular}

\begin{tabular}{c|c|c|c|c|c|c|c|c|c|c|c|c}
\hline $\boldsymbol{H}^{\prime}$ & Mar & Apr & May & Jun & Jul & Aug & Sep & Oct & Nov & Dec & Jan & Feb \\
\hline Mar & & 1 & 0.4656 & 1 & 1 & 1 & 0.0484 & 0.3261 & 1 & $\mathbf{0 . 0 0 5 1} *$ & $\mathbf{0 . 0 0 1 9 *}$ & $\mathbf{0 . 0 0 0 1}$ \\
Apr & 1.628 & & 1 & 1 & 1 & 1 & 1 & 1 & 1 & 1 & 0.5414 & 0.0679 \\
May & 2.454 & 0.827 & & 1 & 1 & 1 & 1 & 1 & 1 & 1 & 1 & 0.7964 \\
Jun & 1.776 & 0.148 & -0.679 & & 1 & 1 & 1 & 1 & 1 & 1 & 0.8031 & 0.1105 \\
Jul & 0.338 & -1.290 & -2.117 & -1.438 & & 1 & 0.1472 & 0.8234 & 1 & $\mathbf{0 . 0 1 8 8 *}$ & $\mathbf{0 . 0 0 7 4}$ & $\mathbf{0 . 0 0 0 4} *$ \\
Aug & 0.804 & -0.824 & -1.650 & -0.971 & 0.466 & & 0.5756 & 1 & 1 & 0.0955 & 0.0418 & $\mathbf{0 . 0 0 3 1}$ \\
Sep & 3.181 & 1.554 & 0.727 & 1.406 & 2.844 & 2.377 & & 1 & 1 & 1 & 1 & 1 \\
Oct & 2.580 & 0.952 & 0.125 & 0.804 & 2.242 & 1.776 & -0.602 & & 1 & 1 & 1 & 1 \\
Nov & 2.126 & 0.499 & -0.328 & 0.351 & 1.789 & 1.322 & -1.055 & -0.454 & & 1 & 1 & 0.3231 \\
Dec & $\mathbf{3 . 7 8 3}$ & 2.155 & 1.329 & 2.007 & $\mathbf{3 . 4 4 5}$ & 2.979 & 0.602 & 1.203 & 1.657 & & 1 & 1 \\
Jan & $\mathbf{4 . 0 2 7}$ & 2.400 & 1.573 & 2.252 & $\mathbf{3 . 6 9 0}$ & 3.223 & 0.846 & 1.448 & 1.901 & 0.244 & & 1 \\
Feb & $\mathbf{4 . 7 0 9}$ & 3.082 & 2.255 & 2.934 & $\mathbf{4 . 3 7 2}$ & $\mathbf{3 . 9 0 5}$ & 1.528 & 2.130 & 2.583 & 0.926 & 0.682 & \\
\hline
\end{tabular}

\begin{tabular}{c|c|c|c|c|c|c|c|c|c|c|c|c}
\hline $\boldsymbol{J}^{\prime}$ & Mar & Apr & May & Jun & Jul & Aug & Sep & Oct & Nov & Dec & Jan & Feb \\
\hline Mar & & 1 & 1 & 1 & 1 & 1 & 1 & 1 & 1 & 1 & 1 & 1 \\
Apr & -0.405 & & 1 & 1 & 1 & 1 & 1 & 1 & 1 & 1 & 1 & 1 \\
May & -0.109 & 0.296 & & 1 & 1 & 1 & 1 & 1 & 1 & 1 & 1 & 1 \\
Jun & -0.084 & 0.322 & 0.026 & & 1 & 1 & 1 & 1 & 1 & 1 & 1 & 1 \\
Jul & -0.354 & 0.051 & -0.245 & -0.270 & & 1 & 1 & 1 & 1 & 1 & 1 & 1 \\
Aug & -0.595 & -0.190 & -0.486 & -0.512 & -0.241 & & 1 & 1 & 1 & 1 & 1 & 1 \\
Sep & 0.885 & 1.290 & 0.994 & 0.968 & 1.239 & 1.480 & & 0.9938 & 0.3508 & 1 & 0.56 & 1 \\
Oct & -1.284 & -0.878 & -1.174 & -1.200 & -0.930 & -0.689 & -2.169 & & 1 & 1 & 1 & 1 \\
Nov & -1.670 & -1.264 & -1.560 & -1.586 & -1.316 & -1.075 & -2.555 & -0.386 & & 1 & 1 & 0.4734 \\
Dec & 0.171 & 0.576 & 0.280 & 0.254 & 0.524 & 0.766 & -0.714 & 1.454 & 1.840 & & 1 & 1 \\
Jan & -1.503 & -1.097 & -1.393 & -1.419 & -1.149 & -0.907 & -2.387 & -0.219 & 0.167 & -1.673 & & 0.7438 \\
Feb & 0.779 & 1.184 & 0.888 & 0.862 & 1.133 & 1.374 & -0.106 & 2.062 & 2.448 & 0.608 & 2.281 & \\
\hline
\end{tabular}

